\title{
Article \\ Phytoextraction and Antioxidant Defense of Mangrove Seedling (Kandelia obovata) to Inorganic Arsenate Exposure
}

\author{
Guirong $\mathrm{Wu}^{1, *,+}$, Kang Mei ${ }^{2, \dagger}$, Caimei He ${ }^{1}$, Sujuan Wang ${ }^{1}$ and Liling Jiang ${ }^{3}$ \\ 1 College of Food and Biological Engineering, Hezhou University, Hezhou 542899, China; \\ shwjs@126.com (C.H.); wangsujuanx@163.com (S.W.) \\ 2 College of Ocean and Earth Sciences, Xiamen University, Xiamen 361102, China; meikang168@xmu.edu.cn \\ 3 Office of Academic Research, Hezhou University, Hezhou 542899, China; jianglilin2009@163.com \\ * Correspondence: hzwgr510@163.com \\ $\dagger$ These authors contributed equally to this work.
}

Citation: Wu, G.; Mei, K.; He, C.; Wang, S.; Jiang, L. Phytoextraction and Antioxidant Defense of Mangrove Seedling (Kandelia obovata) to Inorganic Arsenate Exposure. Water 2022, 14, 643. https://doi.org/ 10.3390/w14040643

Academic Editors: Ashwani Kumar Tiwari and Jian Liu

Received: 15 December 2021 Accepted: 15 February 2022 Published: 18 February 2022

Publisher's Note: MDPI stays neutral with regard to jurisdictional claims in published maps and institutional affiliations.

Copyright: (C) 2022 by the authors. Licensee MDPI, Basel, Switzerland. This article is an open access article distributed under the terms and conditions of the Creative Commons Attribution (CC BY) license (https:// creativecommons.org/licenses/by/ $4.0 /)$.

\begin{abstract}
Increasing arsenic (As) pollution is posing potential endangerment to mangrove wetland ecosystems. Mangrove phytoextraction, translocation, and responses to As exposure must be urgently addressed. In this study, the growth and physiological response of Kandelia obovata seedlings were examined after addition of $25-200 \mathrm{mg} \mathrm{kg}^{-1}$ As under sediment culture conditions. Results showed that the seedling morphological variations were not significant below $100 \mathrm{mg} \mathrm{kg}^{-1}$ compared to the control group, indicating superoxide dismutase, peroxidase, and catalase synergetic interaction to resist the As exposure. High As concentrations (150-200 mg kg-1) inhibited the seedling growth accompanied by a significant increase in malondialdehyde content and decrease in activities of antioxidant enzymes. Toxicity symptoms and mortality appeared in $200 \mathrm{mg} \mathrm{kg}^{-1} \mathrm{As}$, presumably because the plant reached the limit of As tolerance. Besides, As accumulated mainly in roots, accounting for $87.04-97.85 \%$ of the total As, and the bioaccumulation factor (BCF) was $>100 \%$. However, the $\mathrm{BCF}$ and translocation factor (TF) in stems and leaves were below unity, illustrating a weak capacity of transferring As to aerial parts of the seedlings. Overall, K. obovata is a potential remediated species in polluted coastal wetlands due to high phytoextraction capacity and high tolerance to As exposure.
\end{abstract}

Keywords: Kandelia obovata; arsenic; antioxidant enzymes; bioaccumulation factor; translocation factor

\section{Introduction}

Mangroves are evergreen, growing in tropical or subtropical coastal intertidal wetlands. As the main producers of estuaries and wetland ecosystems, mangroves play a critical role in preventing waves, reinforcing embankments, protecting benthic biodiversity, and maintaining the balance of mangrove ecosystems [1-3]. During the past decade, large numbers of wastewater pollutants containing heavy metals were discharged into mangrove wetlands $[4,5]$. The mangrove systems have become the main repository of heavy metals because of their specific physico-chemical properties, such as a high content of sulfides, organic matter, and clay, which promotes the adsorption and precipitation of heavy metals in the sediments [6-8]. Arsenic (As) is a toxic metalloid and carcinogen widely existing in natural environments [5]. Many works have indicated the As accumulation trends in mangrove wetlands [5,9]. In the case of Pearl River port in Guangdong Province, China, from the Seventh Five-Year Plan Period (1986-1990) to 2018-2019, the content of As in the sediments increased from 8.9 to $52.08 \mathrm{mg} \mathrm{kg}^{-1}$ [9]. The As content in the intertidal plain and mangrove sediments of Shenzhen Bay was up to 152.4 and $199.66 \mathrm{mg} \mathrm{kg}^{-1}$, respectively [10]. Additionally, the As content was also relatively high, reaching 35 and $70 \mathrm{mg} \mathrm{kg}^{-1}$ in the mangrove sediments of Sydney (Australia) and Espirito Santo (Brazil), respectively [11,12]. However, potential impacts of increasing As pollution on the mangrove ecosystems and the As phytoextraction performance of mangroves need to be addressed. 
Kandelia obovata (K. obovata) is not only the most widely distributed mangrove species in China, but also a candidate for phytostabilization and ecological restoration of heavy metals in the coastal mangrove wetland system in southeast China $[13,14]$. Moreover, the mangrove possesses high tolerance to heavy metal $(\mathrm{Cu}, \mathrm{Cd}, \mathrm{Zn}, \mathrm{Pb}, \mathrm{Hg}$, etc.) contamination [15-19]. Liu et al. (2014) studied the distribution of As in plants, waters, and sediments of mangrove wetlands and concluded that $K$. obovata possesses a high phytoextraction ability to As [20]. Heavy metals taken up by the plant may induce the production of numerous reactive oxygen species (ROS) in cells that lead to the peroxidation of unsaturated fat in cell membrane components and damage the cell membrane structure [15]. In addition, the malondialdehyde (MDA) level, which is an important indicator of membrane lipid peroxidation, increases in different tissues [19]. Meanwhile, the antioxidant enzymes such as superoxide dismutase (SOD), peroxidase (POD), and catalase (CAT) can scavenge ROS [21] and reduce oxidative stress, while changes in their activities can reflect the degree of plant tolerance to heavy metal stresses $[15,17,22]$. In previous work, the metalloid As had been found to induce oxidative stress in seedlings (Cajanus cajan) after exposure to $10 \mu \mathrm{mol} \mathrm{L}{ }^{-1}$ As in the form of $\mathrm{Na}_{3} \mathrm{AsO}_{4}$ for 5 days, and much higher $\mathrm{H}_{2} \mathrm{O}_{2}, \mathrm{O}_{2}{ }^{-}$, and MDA contents were observed as compared with unstressed plants [23]. Recently, Kumar et al. reported that a genetically modified rice plant with a high-affinity sulphate transporter (OsSultr1;1) reduces oxidative burst of superoxide radicals and hydrogen peroxide under As exposure [24]. These works revealed the crucial role of the defense regulator in plants to As exposure, releasing ROS and activating the antioxidant defense system [25].

Nevertheless, there is still a gap in the knowledge of phytoextraction response and antioxidant tolerance of mangrove seedlings to As. In this study, a mangrove sediment environment was simulated to investigate the effects of As concentration on the growth, antioxidant enzyme activities, As accumulation, and migration in the mangrove seedlings. The toxic effects of As pollution on the seedlings were investigated, providing information on phytoextraction capability and tolerance of $K$. obovata seedlings to As exposure.

\section{Materials and Methods}

\subsection{Plant Material and Sampling}

Healthy and same-size hypocotyls of K. obovata mangrove plants were collected from the mangrove wetland in the Jiulong estuary, Fujian Province $\left(24^{\circ} 24^{\prime} \mathrm{N}, 117^{\circ} 55^{\prime} \mathrm{E}\right)$. Then, healthy and mature hypocotyls of the same size were selected and soaked in $1 \%$ o potassium permanganate solution for $1.5 \mathrm{~h}$ for surface disinfection before heavy metal treatment.

\subsection{Experimental Design}

The cultivated soil was collected from a subsurface sediment near the site of hypocotyls collection. The physiochemical characteristics of the sediment are summarized in Table 1. After removing debris from the collected sediments and homogeneous mixing, pure $\mathrm{Na}_{2} \mathrm{HAsO}_{4} \cdot 7 \mathrm{H}_{2} \mathrm{O}$ was added to the sediments, thoroughly mixed, and stored in the dark for 1 month. Then, the prepared sediment planted with hypocotyls was packed into rectangular glass culture boxes: 40 (length) $\times 30$ (width) $\times 25$ (height) $\mathrm{cm}^{3}$, containing $5 \mathrm{~kg}$ of sediment and five same-size hypocotyls in each carrier. The six As concentrations of 0,25 , $50,100,150$, and $200 \mathrm{mg} \mathrm{kg}^{-1}$ relatively to dry weight (DW) sediment were added to the boxes. Each As concentration level was added in triplicate, then the boxes were cultured in a greenhouse with natural light at $25^{\circ} \mathrm{C}$. All the boxes were kept wet by adding a small volume of water to prevent sample drying. All the parameters were determined in plants harvested after 16-month cultivation. 
Table 1. Physicochemical characteristics of original collected sediment for seedling culture.

\begin{tabular}{|c|c|c|c|c|c|c|}
\hline $\begin{array}{c}\text { Total As } \\
\left(\mathrm{mg} \mathrm{kg}^{-1}\right)\end{array}$ & $\begin{array}{c}\text { Organic } \\
\text { Matter } \\
\left(\mathrm{mg} \mathrm{kg}^{-1}\right)\end{array}$ & $\begin{array}{c}\text { Available } \\
\mathrm{N} \\
\left(\mathrm{mg} \mathrm{kg}^{-1}\right)\end{array}$ & $\begin{array}{c}\text { Available } \\
P \\
\left(\mathrm{mg} \mathrm{kg}^{-1}\right)\end{array}$ & $\begin{array}{c}\text { Available } \\
\text { K } \\
\left(\mathrm{mg} \mathrm{kg}^{-1}\right)\end{array}$ & $\begin{array}{c}\text { Cation Exchange } \\
\text { Capacity } \\
\left(\mu \mathrm{mol} \mathrm{kg} \mathrm{kg}^{-1}\right)\end{array}$ & $\mathrm{pH}$ \\
\hline 20.81 & 3.08 & 98.42 & 27.43 & 617.93 & 17.57 & 7.11 \\
\hline
\end{tabular}

\subsection{Sampling and Analysis}

\subsubsection{Determination of Seedling Height and Biomass}

The seedling stem height was measured, and the biomass of roots, stems, and leaves of K. obovata were also weighed (BSA124S, Sartorius Group, Beijing, China) after carefully harvesting the plant. The plant parts were carefully killed at $105{ }^{\circ} \mathrm{C}$ for $30 \mathrm{~min}$, then, the samples were dried at $70^{\circ} \mathrm{C}$ to constant weight, and the dry weight and moisture content were calculated. The rest of the fresh samples were used for determination of physiological indexes.

\subsubsection{Determination of the Malondialdehyde in Plant}

Half a gram of plant sample was added to $5 \mathrm{~mL} 5 \%$ TCA and homogenized in a centrifuge at $3000 \mathrm{r} \mathrm{min}^{-1}$ for $10 \mathrm{~min}$ (Allegra 64R, Beckman Coulter, Inc., Brea, CA, USA). Later, $2 \mathrm{~mL}$ of supernatant with $2 \mathrm{~mL} 0.67 \%$ TBA was added to the mixture and boiled for $30 \mathrm{~min}$ on a $100{ }^{\circ} \mathrm{C}$ water bath, cooled, and centrifuged again. Then, the absorbance at $450 \mathrm{~nm}$ (A450), $532 \mathrm{~nm}$ (A532), and $600 \mathrm{~nm}$ (A600) of supernatant samples was measured using a spectrometer (TU-1901, Beijing Pusi Co., Ltd., Beijing, China). The following equation was used to calculate the MDA content $(\mu \mathrm{mol} / \mathrm{g})$ per DW of plant [26].

$$
\mathrm{C}\left(\mu \mathrm{mol} \mathrm{L}{ }^{-1}\right)=6.45\left(\mathrm{~A}_{532}-\mathrm{A}_{600}\right)-0.56 \mathrm{~A}_{450}
$$

where $A_{450}, A_{532}$, and $A_{600}$ represent the absorbance values at $450 \mathrm{~nm}, 532 \mathrm{~nm}$, and $600 \mathrm{~nm}$, respectively.

\subsubsection{Determination of Antioxidant Enzyme Activity in Plant}

The mature leaves and root tips of seedlings were extracted with enzyme solution [26] by weighing $0.5 \mathrm{~g}$ of leaves and root tips each and putting them into an ice bath mortar, adding 2-mL precooled phosphoric acid buffer and ground to a pulp. Then, the mortar with phosphoric acid buffer was rinsed twice or thrice at a constant volume of $10 \mathrm{~mL}$. After centrifuging at 10,000 $\mathrm{r} \mathrm{min}-1$ for $20 \mathrm{~min}$ at $4{ }^{\circ} \mathrm{C}$, the enzyme extract solution applied in the test of superoxide dismutase (SOD), peroxidase (POD), and catalase (CAT) activities was separated from the supernatant.

SOD: A reaction mixture containing $0.3 \mathrm{~mL}$ of $130 \mu \mathrm{mol} \mathrm{L}-1$ methionine, $0.3 \mathrm{~mL}$ of $750 \mu \mathrm{mol} \mathrm{L}^{-1}$ EDTA-Na $2,0.3 \mathrm{~mL}$ of $750 \mu \mathrm{mol} \mathrm{L}^{-1}$ nitroblue tetrazolium chloride, and $0.3 \mathrm{~mL}$ of $20 \mu \mathrm{mol} \mathrm{L}{ }^{-1}$ riboflavin was added to the enzyme extract solution. At the beginning, the test tube with the reaction mixture was put into a constant temperature incubator under illumination of 4000 lux for $20 \mathrm{~min}$. The reaction was stopped by placing the tube in the dark. The absorbance was recorded at $560 \mathrm{~nm}$ [26].

POD: A reaction mixture of $2.9 \mathrm{~mL}$ of $0.05 \mathrm{~mol} \mathrm{~L}^{-1}$ sodium phosphate buffer (pH 5.5) was used for evaluating the activity of the POD enzyme. The preparation solutions were $1 \mathrm{~mL}$ of $2 \% \mathrm{H}_{2} \mathrm{O}_{2}, 1 \mathrm{~mL}$ of guaiacol, and $0.1 \mathrm{~mL}$ of enzyme extract. Then, $2 \mathrm{~mL}$ of $20 \%$ trichloroacetic acid was added to stop the reaction. The absorbance was recorded at $470 \mathrm{~nm}[26]$.

CAT: $2.5 \mathrm{~mL}$ of enzyme extract and $2.5 \mathrm{~mL}$ of $0.1 \mathrm{~mol} \mathrm{~L}^{-1} \mathrm{H}_{2} \mathrm{O}_{2}$ were added into a triangular flask kept in a $30{ }^{\circ} \mathrm{C}$ water bath for $10 \mathrm{~min}$. Then, $2.5 \mathrm{~mL}$ of $10 \% \mathrm{H}_{2} \mathrm{SO}_{4}$ was added immediately to ensure drastic extraction. The pretreated reaction was sensitized by a pink color appearance by adding $0.1 \mathrm{~mol} \mathrm{~L}^{-1}$ of $\mathrm{MnO}_{4}$ solution for 30-min incubation [26]. 


\subsubsection{Determination of the Total As Concentration in Plants}

The mature leaves, stems, and roots of seedlings were classified into groups, washed with deionized water, dried at $50{ }^{\circ} \mathrm{C}$ for $48 \mathrm{~h}$, and ground through a 100-mesh nylon sieve [20]. A $0.5 \mathrm{~g}$ sample was weighed, then $7 \mathrm{~mL}$ of concentrated $\mathrm{HNO}_{3}$ and $2 \mathrm{~mL}$ of $\mathrm{H}_{2} \mathrm{O}_{2}$ were added. After that, the mixture was heated during $7 \mathrm{~min}$ to $120^{\circ} \mathrm{C}$, held for $3 \mathrm{~min}$, then heated up $180^{\circ} \mathrm{C}$ for $10 \mathrm{~min}$, finally held for $15 \mathrm{~min}$ using a high-throughput closed microwave digestion system (CEM Mars 5, Matthews, NC, USA). The total As was digested, diluted, and measured in a volume of $50 \mathrm{~mL}$ by inductively coupled plasma mass spectrometry (Perkin Elmer Elan DRC-E, Waltham, MA, USA).

The bioaccumulation factor (BCF) and translocation factor (TF) were calculated to find the absorption capacity and transport capacity of As from sediments to plants using the following formula [20]:

$$
\mathrm{BCF}=\text { As concentration of plant organ / As amount in soil }
$$

$$
\mathrm{TF}=\text { As concentration of plant organ/As concentration of root }
$$

\subsection{Data Analysis}

Data analysis of variance (one-way ANOVA) and correlation analyses were performed using SPSS 22.0 software (SPSS Inc., Chicago, IL, USA), and the significant differences between the groups were compared with the LSD test. The diagrams were drawn using Origin 21 (OriginLab Software, Northampton, MA, USA).

\section{Results}

\subsection{The Effect of As Exposure on the Growth of Mangrove Seedlings}

The effects of As exposure on the growth of seedlings is shown in Table 2. Under 25-100 $\mathrm{mg} \mathrm{kg}^{-1}$ As concentration, no obvious difference in the height of seedlings was registered compared to the control $(p>0.05)$, while the height and biomass significantly reduced $(p<0.05)$ at As concentration of $150 \mathrm{mg} \mathrm{kg}^{-1}$. Under the exposure of $200 \mathrm{mg} \mathrm{kg}^{-1}$ As, the height, biomass of roots, stems, and leaves dramatically decreased to $75.98 \%, 45.04 \%$, $63.44 \%$, and $25.5 \%$ of the control sample, respectively $(p<0.05)$. In particular, the egregious symptoms like blackening of the roots, weak generation of new roots, only 4-5 leaves remaining, as well as inhibition of the seedlings growth were observed, with a mortality rate of $20 \%$.

Table 2. The effect of As exposure on growth and survival rate of Kandelia obovata seedlings.

\begin{tabular}{cccccc}
\hline As $\left(\mathbf{m g ~ k g}^{-\mathbf{1}}\right)$ & $\begin{array}{c}\text { Stem High } \\
(\mathbf{c m})\end{array}$ & $\begin{array}{c}\text { Root Biomass } \\
(\mathbf{g ~ D W})\end{array}$ & $\begin{array}{c}\text { Stem Biomass } \\
\mathbf{( g ~ D W})\end{array}$ & $\begin{array}{c}\text { Leaf Biomass } \\
(\mathbf{g ~ D W})\end{array}$ & $\begin{array}{c}\text { Survival Rate } \\
(\mathbf{\%})\end{array}$ \\
\hline $\mathrm{CK}$ & $42.50 \pm 2.58 \mathrm{c}$ & $11.14 \pm 1.45 \mathrm{c}$ & $5.85 \pm 0.35 \mathrm{~b}$ & $3.99 \pm 0.83 \mathrm{c}$ & 100 \\
25 & $43.22 \pm 2.25 \mathrm{c}$ & $10.67 \pm 1.81 \mathrm{c}$ & $5.47 \pm 0.55 \mathrm{~b}$ & $4.90 \pm 0.83 \mathrm{c}$ & 100 \\
50 & $39.60 \pm 5.16 \mathrm{bc}$ & $10.39 \pm 1.10 \mathrm{bc}$ & $5.19 \pm 0.24 \mathrm{~b}$ & $4.01 \pm 0.53 \mathrm{c}$ & 100 \\
100 & $39.52 \pm 3.14 \mathrm{bc}$ & $9.27 \pm 1.13 \mathrm{bc}$ & $5.19 \pm 0.18 \mathrm{~b}$ & $2.93 \pm 0.37 \mathrm{bc}$ & 100 \\
150 & $35.77 \pm 2.91 \mathrm{ab}$ & $8.16 \pm 1.63 \mathrm{~b}$ & $3.91 \pm 0.28 \mathrm{a}$ & $2.42 \pm 0.56 \mathrm{~b}$ & 100 \\
200 & $32.29 \pm 3.09 \mathrm{a}$ & $5.02 \pm 0.71 \mathrm{a}$ & $3.71 \pm 0.36 \mathrm{a}$ & $0.98 \pm 0.16 \mathrm{a}$ & 80
\end{tabular}

Note: Data are means \pm standard errors of three replicates. Values within the same column followed by different letters are significant $(p<0.05, n=3)$.

\subsection{Effects of As Exposure on MDA and Antioxidant Enzymes of Mangrove Seedlings}

The MDA content in roots and leaves showed an increasing trend with the As concentration in roots and leaves (Figure 1A). In the range of $25-100 \mathrm{mg} \mathrm{kg}^{-1} \mathrm{As}$, there is no significant impact on MDA $(p>0.05)$. However, the MDA sharply increased under treatments with 150 and $200 \mathrm{mg} \mathrm{kg}^{-1}$ As $(p<0.05)$, which constituted $44.78 \%$ and $64.14 \%$ of the control, respectively. 

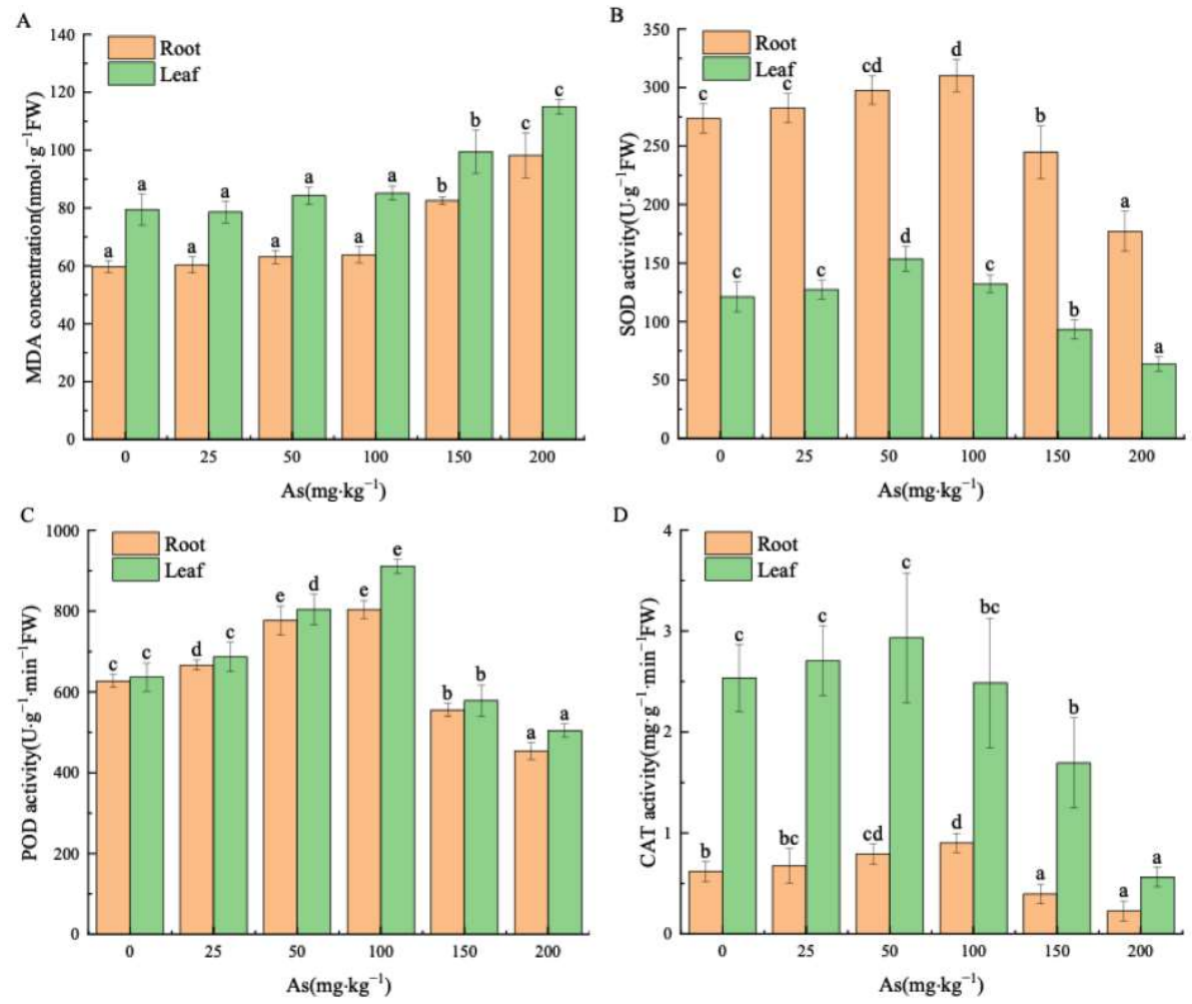

Figure 1. Effect of As exposure on MDA and antioxidant enzyme activities in the seedlings. (A) MDA concentration (nmol g ${ }^{-1} \mathrm{FW}$ ) in the root and the leaf; (B) SOD activity ( $\mathrm{U} \mathrm{g}^{-1} \mathrm{FW}$ ); (C) POD activity $\left(\mathrm{U} \mathrm{g}^{-1} \mathrm{~min}^{-1} \mathrm{FW}\right)$; (D) CAT activity $\left(\mathrm{mg} \mathrm{g}^{-1} \mathrm{~min}^{-1} \mathrm{FW}\right)$. Treatments labeled with different letters are significantly different $(p<0.05)$.

The antioxidant enzyme activity in roots and leaves increased with rising As concentration (Figure 1B-D) followed by a remarkable decline at As concentration above $150 \mathrm{mg} \mathrm{kg}^{-1}$, which was lower than the control.

The SOD enzyme activities in roots and leaves of seedlings increased notably to the peak values of $153.56 \mathrm{U} \mathrm{g}^{-1}$ and $310 \mathrm{U} \mathrm{g}^{-1}$ at As concentrations of $50 \mathrm{mg} \mathrm{kg}^{-1}$ and $100 \mathrm{mg} \mathrm{kg}^{-1}$, respectively $(p<0.05)$, whereas they were reduced to a minimum of $52.73 \%$ and $64.70 \%$ of the control group at $200 \mathrm{mg} \mathrm{kg}^{-1}$ As (Figure 1B).

The POD enzyme activities in roots and leaves of the seedlings reached the maximum values of $143 \%$ and $128 \%$ of the control $(p<0.05)$ at $100 \mathrm{mg} \mathrm{kg}^{-1}$ As concentration (Figure 1C). Treatment with $200 \mathrm{mg} \mathrm{kg}^{-1}$ As caused the drop of POD activities to the lowest values of $79.22 \%$ and $72.44 \%$ of the control.

At a concentration of $50 \mathrm{mg} \mathrm{kg}^{-1}$ As, the CAT enzyme activity in the roots slightly increased by 1.16 times that of the control $(p>0.05)$, while it rose sharply to 1.45 times that of the control at $100 \mathrm{mg} \mathrm{kg}^{-1}$ As $(p<0.05)$. Nevertheless, under As exposure of $200 \mathrm{mg} \mathrm{kg}^{-1}$, the CAT activities of roots and leaves reduced to $22.23 \%$ and $36.34 \%$ of the control, respectively $(p<0.05)$. The correlation analysis of antioxidant enzymes in roots and leaves (Table 3) proved a significant positive correlation between the activities of SOD, POD, and CAT enzymes $(p<0.01)$. 
Table 3. Parameter correlations between antioxidant enzyme activities in the seedlings.

\begin{tabular}{lcccccc}
\hline Parameter & Root SOD & Root POD & Root CAT & Leaf SOD & Leaf POD & Leaf CAT \\
\hline Root SOD & 1.000 & & & & \\
Root POD & $0.806^{*}$ & 1.000 & & & \\
Root CAT & $0.851^{*}$ & $0.664^{*}$ & 1.000 & & \\
Leaf SOD & $0.898^{*}$ & $0.824^{*}$ & $0.814^{*}$ & 1.000 & & \\
Leaf POD & $0.890^{*}$ & $0.951^{*}$ & $0.760^{*}$ & $0.887^{*}$ & 1.0 & \\
Leaf CAT & $0.841^{*}$ & $0.855^{*}$ & $0.707^{*}$ & $0.899^{*}$ & $0.878^{*}$ & 1.000 \\
\hline Note: ${ }^{*}$ indicates that the correlation at the 0.01 level was significant.
\end{tabular}

\subsection{Effects of As Exposure on As Accumulation and Translocation in Plant Tissues}

\subsubsection{As Accumulation in Plant Tissues}

Arsenic accumulation increased with input As concentration in roots, stems, and leaves of the seedlings (Figure 2). The As concentration in the three plant parts reached the peak values of $1256.08,16.46$, and $11.19 \mathrm{mg} \cdot \mathrm{kg}^{-1}(31.48,4.78$, and 4.49 times that of the control groups), respectively, at the $200 \mathrm{mg} \mathrm{kg}^{-1}$ As input concentration. Moreover, significant differences were found in the As concentration in roots among all the groups $(p<0.05)$.

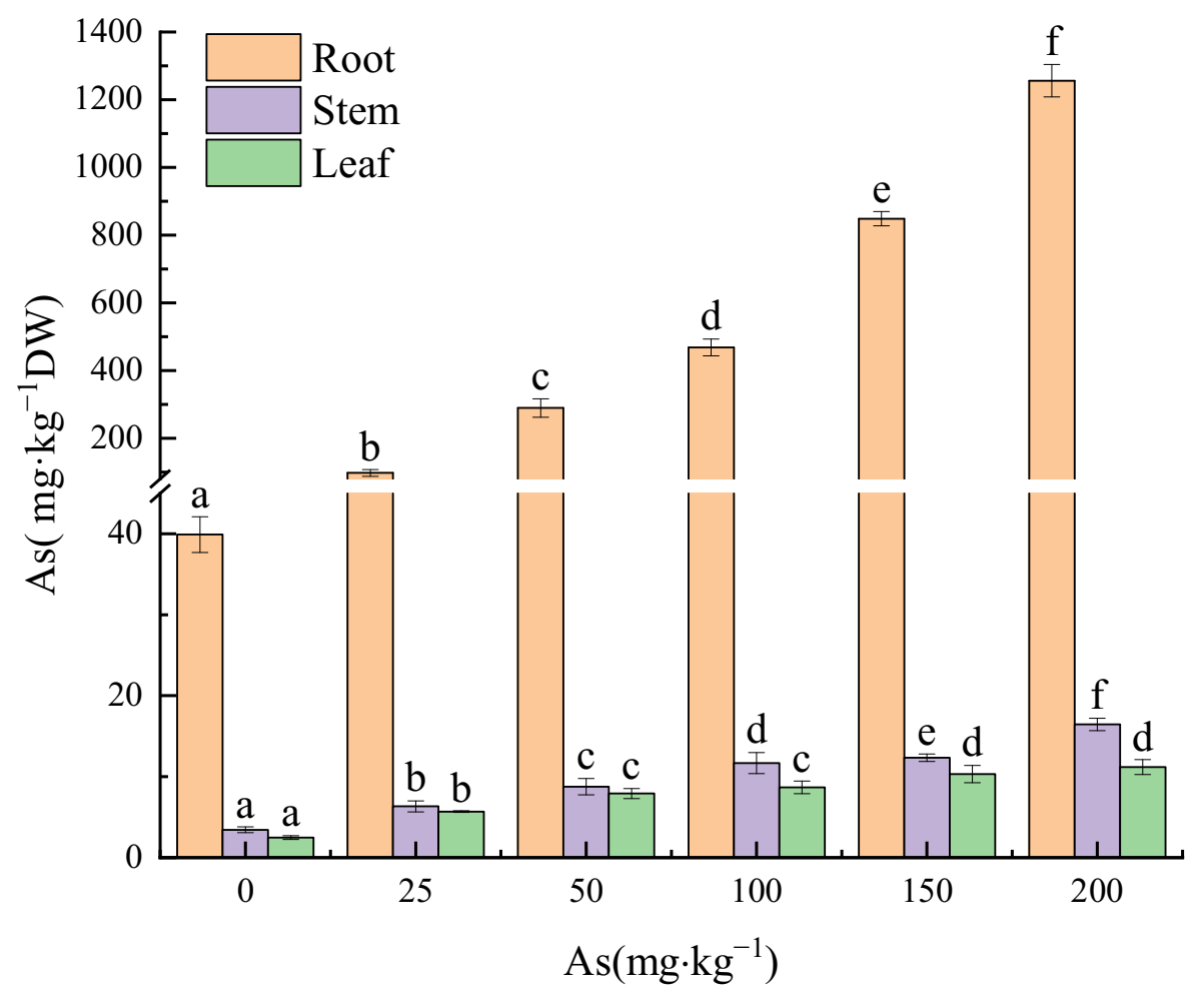

Figure 2. The As concentrations in roots, stems, and leaves of the seedlings in the study. Different letters were indicated significant differences $(p<0.05)$.

Figure 3 shows that with the increase of As input concentration, the proportion of As concentration in root to that in plant tissues was $87.04-97.85 \%$, showing an increasing trend. On the contrary, the As accumulation in stems and leaves showed a downward trend, accounting for $7.49-1.28 \%$ and $5.47-0.87 \%$, respectively. Therefore, the As concentration in the three treatment groups was as follows: roots $>$ stems $>$ leaves. 


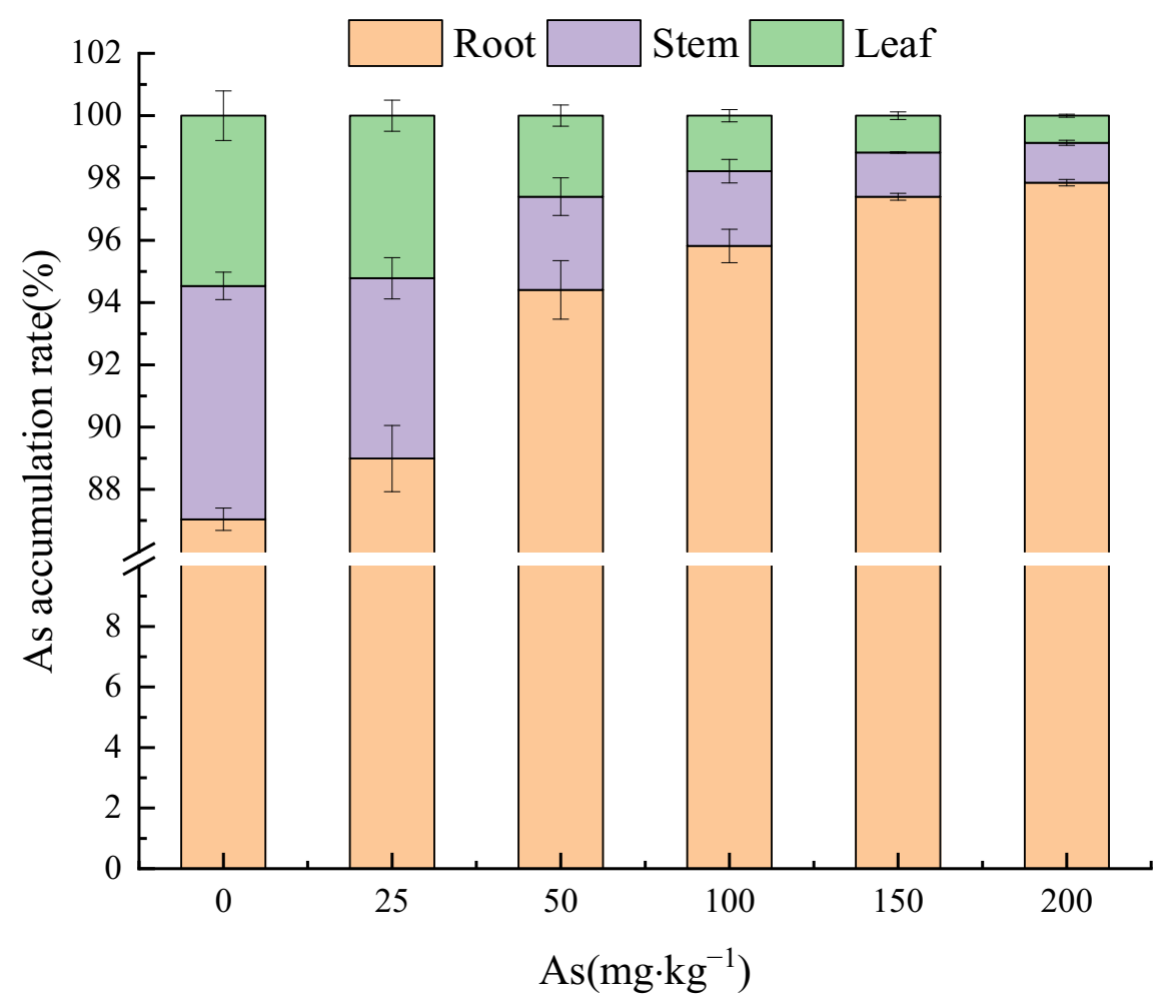

Figure 3. Effects of As added concentration on As accumulation ratios in roots, stems, and leaves of the seedlings.

\subsubsection{Arsenic Transfer in the Plant Parts of the Mangrove Seedlings}

The $\mathrm{BCF}_{\text {root }}$ value for all groups all exceeded unity, within a range of 1.92-5.69 (Figure 4A). Meanwhile, it increased with As concentration, reaching the peak values of 2.96 times that of the control at $200 \mathrm{mg} \mathrm{kg}^{-1}$ As concentration. At the same time, the $\mathrm{BCF}_{\text {stem }}$ and $\mathrm{BCF}_{\text {leaf }}$ values for each As treatment level were below unity, ranging from 0.17 to 0.07 and 0.12 to 0.05 , respectively. Meanwhile, at $200 \mathrm{mg} \mathrm{kg}^{-1}$ input concentration of As, the $\mathrm{BCF}_{\text {stem }}$ and $\mathrm{BCF}_{\text {leaf }}$ values were $45.09 \%$ and $42.3 \%$, correspondingly, of those in the control group. Furthermore, Figure $4 \mathrm{~B}$ shows that the $\mathrm{TF}_{\text {stem/root }}$ and $\mathrm{TF}_{\text {leaf/root }}$ values decreased as concentration increased (Figure 4B), ranging from 0.09 to 0.01 and 0.06 to 0.009 , respectively. The $\mathrm{TF}_{\text {stem/root }}$ and $\mathrm{TF}_{\text {leaf/root }}$ values were $15.24 \%$ and $14.27 \%$ of the control, respectively, at $200 \mathrm{mg} \mathrm{kg}^{-1}$ As input concentration.

A

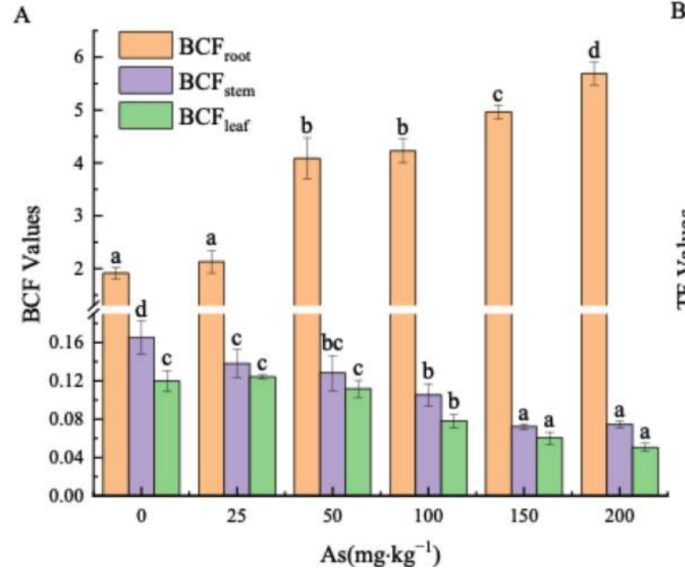

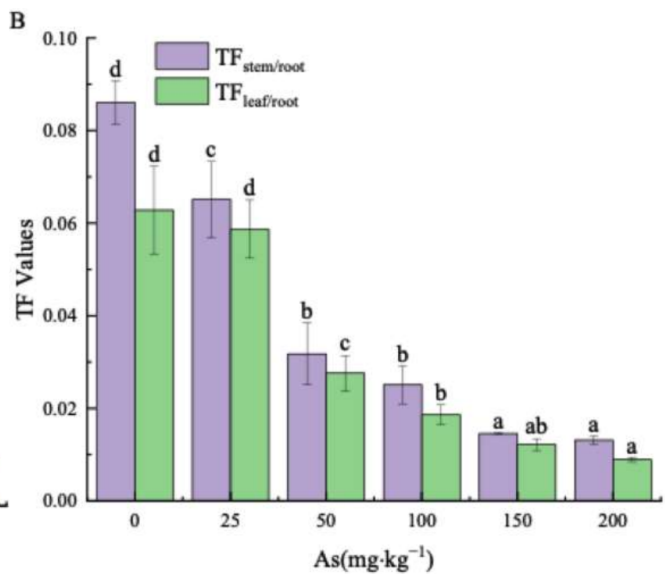

Figure 4. BCF in roots, stems and leaves (A), and TF of As from roots to stems and leaves (B) in the seedlings. Different letters were indicated significant differences $(p<0.05)$. 


\section{Discussion}

\subsection{Effects of As Exposure on the Growth of the Seedlings}

Arsenic is not an essential element in the plant-growing process. Nevertheless, several studies had proven that small amounts of As stimulate plant growth, while high concentrations of As produce toxic effects in plants [27-29]. The toxicity manifested in a shorter length of leaves and stems, the decrease in biomass and photosynthesis, membrane lipid peroxidation, and even affected physiological functions, resulting in abnormal growth of the plant. [27-29]. These basic findings are consistent with our study demonstrating that $K$. obovata seedlings grew normally at low and medium As concentrations of $25-100 \mathrm{mg} \mathrm{kg}^{-1}$ (Table 1), while the seedlings' growth were suppressed at As input concentration reached $150 \mathrm{mg} \mathrm{kg}^{-1}$, where the biomasses of roots, stems, and leaves were distinctly lower than the control. The mortality rate was $20 \%$, and the typical poisoning symptoms were manifested at the As concentration of $200 \mathrm{mg} \mathrm{kg}^{-1}$, which is eventually the limit of tolerance to As. Subsequently, Ren et al. (2021) confirmed that strong toxic action was observed in Typha angustifolia L. at As concentration in soil reaching $200 \mathrm{mg} \mathrm{kg}^{-1}$ [29]. In general, our results are consistent with that publication.

\subsection{Effects of As Exposure on MDA and Antioxidant Enzymes}

Excessive accumulation of heavy metals induces reactive oxygen species (ROS) in plant cells, and MDA reflects the extent of damage to cell membranes. In response, plants activate SOD enzyme to disproportionate ROS into $\mathrm{O}_{2}$ and $\mathrm{H}_{2} \mathrm{O}_{2}$, while POD and CAT decompose $\mathrm{H}_{2} \mathrm{O}_{2}$ into nontoxic $\mathrm{H}_{2} \mathrm{O}$ and $\mathrm{O}_{2}$. In the present study, the antioxidant defense increased along with As concentration, and reached a peak at $100 \mathrm{mg} \mathrm{kg}^{-1}$. Similar research reported that an evident increase in $\mathrm{H}_{2} \mathrm{O}_{2}$ and thiobarbituric acid reactive substances (TBARS) content appeared in two different cultivars of Chenopodium quinoa under As exposure (150 and $300 \mu \mathrm{mol} \mathrm{L}-1 \mathrm{Na}_{3} \mathrm{AsO}_{4}$ ) for 35 days [23]. These three enzymes cooperate to scavenge ROS and avoid its excess, causing peroxidation of biomolecules and membrane lipids in order to protect plants $[30,31]$. In our study, the antioxidant enzyme activity increased and then decreased with As concentration. The MDA concentration did not change significantly within the $25-100 \mathrm{mg} \mathrm{kg}^{-1}$ concentration range, whereas SOD, POD, and CAT enzyme activities in roots and leaves peaked at 50 or $100 \mathrm{mg} \mathrm{kg}^{-1}$ concentration levels. Hence, the antioxidant system is a key mechanism to resist As-induced lipid peroxidation at As concentrations of up to $100 \mathrm{mg} \mathrm{kg}^{-1}$, resulting in slight MDA variation with concentration. The obtained data demonstrated that mangrove plants coordinated the activation of antioxidant defense systems (Table 3) to scavenge excess ROS, maintained ROS homeostasis in seedlings, and improved the plant tolerance to As [16]. The MDA content rose remarkably and the antioxidant enzyme activity declined significantly when the As exposure concentration exceeded $150 \mathrm{mg} \mathrm{kg}^{-1}$. Thus, it was proven that high As concentration induced the production of numerous ROS, exceeding the scavenging capacity of antioxidant enzymes, and the balance of ROS in plants could not be maintained, exacerbating membrane lipid peroxidation. A similar phenomenon was observed when K. obovata was exposured by other heavy metals, such as $\mathrm{Cd}$, $\mathrm{Cu}$, and $\mathrm{Hg}[15,17,32]$. In other words, under contamination with heavy metals the mangrove seedlings may boost antioxidant enzyme activity to enhance resistance. Nevertheless, when the exposure exceeds the tolerance limit, membrane lipid peroxidation damaged the plant defense system, resulting in reduced enzyme activities [15,17,32].

\subsection{The Accumulation and Translocation of As in the Plant}

The important indicators for measuring the ability of plants to accumulate As are concentration, $\mathrm{BCF}$, and $\mathrm{TF}$ of As. The larger the $\mathrm{BCF}$ and $\mathrm{TF}$, the stronger the accumulation and transport capacities [33,34]. Notably, when the accumulation factor exceeds unity, the plant restored the contaminated soil $[20,35,36]$. According to our data on absorption, transportation, and accumulation of As in the seedlings, the As accumulation increased with As input concentration. As mainly accumulated in the roots, accounting for $87.04-97.85 \%$ 
of the total amount, and the maximum value was $1256.08 \mathrm{mg} \mathrm{kg}^{-1}$ (Figure 2). Therefore, the ratio of As accumulation in various plant tissues was as follows: root $>$ stem $>$ leaf (Figure 3). Additionally, the BCF range was 1.92-5.69, which was 11.59-76.33 times more than that in stems and 16.00-112.25 times more than that in leaves (Figure 4A). However, the TFs of stem and leaves were extremely low, below unity (Figure 4B), and declined with increasing As concentration. The low TF indicates that the As exposure affected the ability to transfer As to the aerial parts, such as stem and leaves, blocked As in the underground part, and reduced the harmful effects to the aerial organs. These findings were in agreement with other results under $\mathrm{As}, \mathrm{Cd}, \mathrm{Cu}$, and $\mathrm{Zn}$ stresses [20,37-39]. The As accumulation in the roots might be related to the formation of iron plaque on root surface based on our previous laboratory work. The strong accumulation ability of iron plaque on root surface reduces the toxic effects due to adsorption or coprecipitation of As [40,41]. The other potential causes are fixing As absorbed by roots in the root cell wall [36], or bounding As by sulfhydryl compounds and immobilizing them in the root [42], thus reducing the mobility of As. The tolerance to inorganic arsenite, As(III) of mangrove seedlings manifested in lowering ROL, translocating As, and releasing low-molecular-weight organic acids to reduce As toxicity, and facilitating the As fixation in sediment [43].

The aforementioned results confirm that As accumulated mainly in roots, and the fixation function of roots may be an important protective mechanism for the aerial parts' survival. Furthermore, a linear regression relationship was found between the As concentration in roots and sediments $\left(R^{2}=0.976, p<0.01\right.$, data not shown). The formula demonstrated that the roots of mangrove seedlings may represent the As environmental level and can be used as a biological indicator of As in polluted sediments.

\section{Conclusions}

The experiments performed in this study contribute to the increasing amount of research on the effects of As on K. obovata seedlings. The plant seedlings coordinated activation of the antioxidant enzyme defense system to improve As tolerance while exposed to As concentrations up to $100 \mathrm{mg} \mathrm{kg}^{-1}$. In contrast, high concentrations of As (150-200 $\mathrm{mg} \mathrm{kg}^{-1}$ ) led to excessive membrane lipid peroxidation, significantly reduced antioxidant enzyme activities, and inhibited growth. Particularly, typical symptoms of toxicity and mortality at $200 \mathrm{mg} \mathrm{kg}^{-1}$ As concentration were observed, presumably, indicating that the tolerance limit of resistance to As is reached. Moreover, the root system accumulated the major part for As, and its fixation function played a critical role in protecting the aerial part of the plant, which can be regarded as a biological indicator in sediments contaminated by As. Meanwhile, the high As tolerance and low transport characteristics of seedling roots indicate the mangrove plant as a potential candidate for remediation in As polluted wetlands

Author Contributions: Conceptualization, G.W. and C.H.; formal analysis, G.W., C.H., S.W. and L.J.; funding acquisition, G.W.; investigation, C.H. and S.W.; project administration, G.W.; resources, G.W.; supervision, K.M. and L.J.; validation, G.W., K.M., S.W. and L.J.; writing—original draft, G.W., K.M. and C.H.; writing — review and editing, G.W. and K.M. All authors have read and agreed to the published version of the manuscript.

Funding: This research was funded by National Natural Science Foundation of China, grant number No. 31760163) and the Professional Foundation of Hezhou University, grant number HZUJS201707).

Acknowledgments: We would like to thank Xiamen University for the full technique support and the people who helped us during the study. We also wish to thank the anonymous reviewers for their constructive comments to improve the manuscript.

Conflicts of Interest: The authors declare no conflict of interest.

\section{References}

1. Lin, P. Mangrove Ecosystem in China; Science Press: Beijing, China, 1997. (In Chinese)

2. Barbier, E.B. Valuing ecosystems as productive inputs. Econ. Policy 2007, 22, 177-229. [CrossRef] 
3. Das, S.; Crépin, A.S. Mangroves can provide protection against wind damage during storms. Estuar. Coast. Shelf Sci. 2013, 134, 98-107. [CrossRef]

4. Zhang, Z.W.; Xu, X.R.; Sun, Y.X.; Yu, S.; Chen, Y.S.; Peng, J.X. Heavy metal and organic contaminants in mangrove ecosystems of China: A review. Environ. Sci. Pollut. Res. Int. 2014, 20, 11938-11950. [CrossRef]

5. Mei, K.; Wu, G.R.; Liu, J.C.; Wu, J.J.; Hong, H.L.; Lu, H.L.; Yan, C.L. Dynamics of low-molecular-weight organic acids for the extraction and sequestration of arsenic species and heavy metals using mangrove sediments. Chemosphere 2022, 286, 131820. [CrossRef] [PubMed]

6. Lewis, M.; Pryor, R.; Wilking, L. Fate and effects of anthropogenic chemicals in mangrove ecosystems: A review. Environ. Pollut. 2011, 159, 2328-2346. [CrossRef] [PubMed]

7. Kulkarni, R.; Deobagkar, D.; Zinjarde, S. Metals in mangrove ecosystems and associated biota: A global perspective. Ecotoxicol. Environ. Saf. 2018, 153, 215-228. [CrossRef]

8. Li, J.; Liu, J.C.; Yan, C.L.; Du, D.L.; Lu, H.L. Alleviation effect of iron on cadmium phytotoxicity in mangrove Avicennia marina (Forsk.) Vierh. Chemosphere 2019, 226, 413-420.

9. Niu, A.Y.; Gao, Y.F.; Xu, S.J. Effects of heavy metal pollution on the carbon content of surface sediments of mangroves in the Pearl River Estuary. Acta Ecol. Sin. 2020, 40, 8549-8558. (In Chinese)

10. Li, R.; Chai, M.; Li, R.Y.; Xu, H.L.; Qiu, G.Y. Influence of introduced Sonneratia apetala on nutrients and heavy metals in intertidal sediments, South China. Environ. Sci. Pollut. Res. Int. 2017, 24, 2914-2927. [CrossRef]

11. Mirlean, N.; Medeanic, S.; Garcia, F.A.; Travassos, M.P.; Baisch, P. Arsenic enrichment in shelf and coastal sediment of the Brazilian subtropics. Contin. Shelf Res. 2012, 35, 129-136. [CrossRef]

12. Chaudhuri, P.; Nath, B.; Birch, G. Accumulation of trace metals in grey mangrove Avicennia marina fine nutritive roots: The role of rhizosphere processes. Mar. Pollut. Bull. 2014, 79, 284-292. [CrossRef] [PubMed]

13. Lin, P.; Zhang, Y.H.; Yang, Z.W. Protection and Restoration of Mangroves along the Coast of Xiamen. J. Xiamen Univ. (Nat. Sci.) 2005, 44, 1-6. (In Chinese)

14. Yang, S.; Lu, X.; Liu, X.; Chen, Q.X.; Wang, J.W.; Guo, J.M. Experiment of Kandelia obovata Seedlings in Different Estuaries in Zhejiang. J. Zhejiang Sci Techol. 2021, 41, 60-66. (In Chinese)

15. Zhang, F.Q.; Wang, Y.S.; Lou., Z.P.; Dong, J.D. Effect of heavy metal stress on antioxidative enzymes and lipid peroxidation in leaves and roots of two mangrove plant seedlings (Kandelia candel and Bruguiera gymnorrhiza). Chemosphere 2007, 67, 44-50. [CrossRef] [PubMed]

16. Zhou, Y.Y.; Wang, Y.S.; Inyang, A.I. Eco-physiological differences between five mangrove seedlings under heavy metal stress. Mar. Pollut. Bull. 2021, 172, 112900. [CrossRef] [PubMed]

17. Zhao, H.; Tang, J.; Zheng, W.J. Growth and physiological characteristics of Kandelia obovata seedlings under Cu ${ }^{2+}$ stress. Mar. Sci. 2016, 40, 65-72. (In Chinese)

18. Shen, X.X.; Li, R.L.; Chai, M.W.; Cheng, S.S.; Niu, Z.Y.; Qiu, G.Y. Interactive effects of single, binary and trinary trace metals (lead, zinc and copper) on the physiological responses of Kandelia obovata seedlings. Environ. Geochem. Health 2019, 41, 135-148. [CrossRef]

19. Wu, Y.; Leng, Z.; Li, J.; Yan, C.L.; Wang, X.; Jia, H.; Chen, L.; Zhang, S.; Zheng, X.; Du, D. Sulfur mediated heavy metal biogeochemical cycles in coastal wetlands: From sediments, rhizosphere to vegetation. Front. Environ. Sci. Eng. 2022, 16, 102. [CrossRef]

20. Liu, C.W.; Chen, Y.Y.; Kao, Y.H.; Maji, S.K. Bioaccumulation and translocation of arsenic in the ecosystem of the Guandu Wetland, Taiwan. Wetlands 2014, 34, 129-140. [CrossRef]

21. Bakshi, M.; Ghosh, S.; Chakraborty, D.; Hazra, S.; Chaudhuri, P. Assessment of potentially toxic metal (PTM) pollution in mangrove habitats using biochemical markers: A case study on Avicennia officinalis L. in and around Sundarban, India. Mar. Pollu. Bull. 2018, 133, 157-172. [CrossRef]

22. Wang, F.Z.; Wang, Y.S. Effects of $\mathrm{Cu}^{2+}$ and $\mathrm{Pb}^{2+}$ stress on soluble protein content and activities of antioxidant enzymes in Kandelia obovata seedings. Ecol. Sci. 2020, 39, 10-18. (In Chinese)

23. Yadu, B.; Chandrakar, V.; Tamboli, R.; Keshavkant, S. Dimethylthiourea antagonizes oxidative responses by up-regulating expressions of pyrroline-5-carboxylate synthetase and antioxidant genes under arsenic stress. Int. J. Environ. Sci. Technol. 2019, 16, 8401-8410. [CrossRef]

24. Kumar, S.; Khare, R.; Trivedi, P.K. Arsenic-responsive high-affinity rice sulphate transporter, OsSultr1;1, provides abiotic stress tolerance under limiting sulphur condition. J. Hazard. Mater. 2019, 373, 753-762. [CrossRef] [PubMed]

25. Hasanuzzaman, M.; Bhuyan, M.H.M.; Zulfiqar, F.; Raza, A.; Mohsin, S.M.; Mahmud, J.A.; Fujita, M.; Fotopoulos, V. Reactive oxygen species and antioxidant defense in plants under abiotic stress: Revisiting the crucial role of a universal defense regulator. Antioxidants 2020, 9, 681. [CrossRef] [PubMed]

26. Li, H.S. Principles and Techniques of Plant Physiological Biochemical Experiment; Higher Education Press: Beijing, China, 2004. (In Chinese)

27. Shaibur, M.R.; Kawai, S. Effect of arsenic on visible symptom and arsenic concertation in hydroponic Japanese mustard spinach Environ. Exp. Bot. 2009, 67, 65-70. [CrossRef]

28. Verbruggen, N.; Hermans, C.; Schat, H. Mechanisms to cope with arsenic or cadmium excess in plant. Curr. Opin. Plant Biol. 2009, 12, 364-372. [CrossRef] 
29. Ren, W.; Yang, G.Y.; Liu, Y.G.; Liu, X.; Li, M.Y.; Zhao, R.; Wang, Y. Effect of arsenic stress on the growth of Typha angustiflia L. in plateau wetland and its arsenic tolerance. J. Yunnan Univ. Naural Sci. Edi. 2021, 43, 164-173. (In Chinese)

30. Alscher, R.G.; Erturk, N.; Heath, L.S. Role of superoxide dismutase (SODs) in controlling oxidative stress in plants. J. Exp. Bot. 2002, 53, 1331-1341. [CrossRef]

31. Apel, K.; Hitr, H. Reactive oxygen species: Metabolism, oxidative stress, and signal transduction. Annu. Rev. Plant Biol. 2004, 55, 373-399. [CrossRef]

32. Xie, X.Y.; Weng, B.S.; Zhao, S.Z.; Yan, C.L. Effects of arbuscular mycorrhizal inoculation and Cd stress on the growth and antioxidant enzyme system of Kandelia obovata. J. Xiamen Univ. (Natural Sci.) 2013, 52, 244-253. (In Chinese)

33. Sawidis, T.; Breuste, J.; Mitrovic, M.; Tsigaridas, K. Trees as bioindicator of heavy metal pollution in three European cities. Environ. Pollu. 2011, 159, 3560-3570. [CrossRef]

34. Rodringuez-Bocanegra, J.; Roca, N.; Febrero, A. Assessment of heavy metal tolerance in two plant species growing in experimental disturbed polluted urban soil. J. Soils Sediments 2018, 18, 2305-2317. [CrossRef]

35. Chen, T.B.; Wei, C.Y.; Huang, Z.C.; Huang, Q.F.; Lu, Q.G.; Fan, Z.L. Arsenic accumulation characteristics of Arsenic hyperaccumulator Pteris Vittata L. Chin. Sci. Bull. 2002, 47, 207-210. (In Chinese)

36. Zhang, J.L.; Huang, Y.; Wu, L.F.; Gong, Y.H. Liu, Y.G.; Wang, Y.; Yang, S.L. As subcellular distribution and physiological response of Typha angustifolia L. to as exposure. Ecol. Environ. Sci. 2021, 30, 1042-1050. (In Chinese)

37. Wu, G.R.; Hong, H.L.; Yan, C.L. Arsenic accumulation and translocation in mangrove (Aegiceras corniculatum L.) grown in arsenic contaminated soils. Int. J. Environ. Res. Public Health 2015, 12, 7244-7253. [CrossRef]

38. Li, J.; Yu, J.; Yan, C.L.; Du, D.L.; Lu, H.L. Distribution correlations of cadmium to calcium, phosphorus, sodium and chloridion in mangrove Aegiceras corniculatum root tissues. Mar. Pollut. Bull. 2018, 126, 179-183. [CrossRef] [PubMed]

39. Li, J.; Yu, J.; Du, D.L.; Liu, J.C.; Lu, H.L.; Yan, C.L. Analysis of anatomical changes and cadmium distribution in Aegiceras corniculatum (L.) Blanco roots under cadmium stress. Mar. Pollut. Bull. 2019, 149, 110536. [CrossRef] [PubMed]

40. Blute, N.K.; Brabander, D.J.; Hemond, H.F.; Sutton, S.R.; Rivers, M.L. Arsenic sequestration by ferric iron plaque on cattail roots. Environ. Sci. Technol. 2004, 38, 6074-6077. [CrossRef] [PubMed]

41. Hu, M.; Li, F.B.; Liu, C.P.; Wu, W.J. The diversity and abundance of As(III) oxidizers on root iron plaque is critical for arsenic bioavailability to rice. Sci. Rep. 2015, 5, 1-10. [CrossRef]

42. Wu, G.R.; Hong, H.L.; Yan, C.L. Influence of sulfur supply on thiols in Aegiceras corniculatum(L.) Blanco under As stress. J. Xiamen Univ. (Natural Sci.) 2016, 55, 55-59. (In Chinese)

43. Mei, K.; Liu, J.; Fan, J.; Guo, X.; Wu, J.; Zhou, Y.; Lu, H.; Yan, C. Low-level arsenite boosts rhizospheric exudation of low-molecularweight organic acids from mangrove seedlings (Avicennia marina): Arsenic phytoextraction, removal, and detoxification. Sci. Total Environ. 2021, 775, 145685. [CrossRef] [PubMed] 